\title{
PEMANFAATAN OBAT-OBAT TRADISIONAL DALAM MENCEGAH DAN MENGOBATI PENYAKIT TYPHUS SEBAGAI UPAYA PENINGKATAN HIDUP SEHAT PADA MASYARAKAT PAGESANGAN BARAT MATARAM
}

\author{
Muktiningsih Nurjayadi $^{1)}$, Listya Ayu Saraswati ${ }^{2)}$ \\ Program Studi Kimia, Fakultas Matematika dan Ilmu Pengethauan Alam, \\ Universitas Negeri Jakarta ${ }^{l)}$ \\ Bina Nusantara University, Program Studi Manajemen Bisnis, BINUS Online Learning Jakarta Indonesia2) \\ E-mail: muktiningsih@unj.ac.id
}

\begin{abstract}
Typhoid disease is a small intestinal infection caused by Salmonella typhi bacteria. The disease is known to attack all ages from children to adults. Therefore, it is necessary a way to provide understanding of typhoid and alternative prevention. The purpose of Community Service (P2M) is to increase knowledge about the Utilization of Traditional Medicines In Preventing And Treating Typhoid Disease As Efforts To Improve Healthy Life In The Society Of West Pagesangan Mataram. The method used is training with information discussion, question and answer. The strategic target audience that plays a role is housewives, teenagers, and educators at SDIT Anak Sholeh, with the address is Jl. Merdeka Raya, Gang Merdeka XVII Pagesangan Mataram. In the training showed the positive response from the participants. This was observed from the participants' further seriousness and curiosity about traditional medicine for typhoid, and the presence of questions raised during the training process. In addition, participants have a desire to implement the knowledge gained to improve the health of families and communities. The random evaluation in the form of short questions and interviews shows the participants can answer well and provide examples of traditional medicine in the environment that can be utilized to prevent typhoid disease other than those delivered by the source. Based on the data obtained can be concluded that the process of improving understanding Pagesangan Mataram community has been successfully implemented. This activity is expected to be used as a first step to increase a community's role in maintaining health and the environment and particular to be followed up continuously so that people feel more contribute and needed.
\end{abstract}

Keyword: Typhoid diseases, Traditional Medicines, SDIT Anak Sholeh, Pagesangan Mataram

\section{ABSTRAK}

Penyakit typhus merupakan penyakit infeksi usus halus yang disebabkan oleh bakteri Salmonella typhi. Penyakit ini diketahui menyerang semua usia mulai anak-anak sampai orang dewasa. Oleh karena itu diperlukan suatu cara untuk memberikan pemahaman terhadap penyakit tipus dan alternative pencegahannya. Tujuan Pengabdian Masyarakat (P2M) ini adalah meningkatkan pengetahuan tentang Pemanfaatan Obat-Obat Tradisional Dalam Mencegah Dan Mengobati Penyakit Typhus Sebagai Upaya Peningkatan Hidup Sehat Pada Masyarakat Pagesangan Barat Mataram. Metode yang digunakan adalah pelatihan dengan metode ceramah, diskusi informasi, dan tanya jawab. Khalayak sasaran strategis yang turut berperan adalah ibu-ibu rumah tangga, remaja, dan pendidik di SDIT Anak Sholeh, Jl. Merdeka Raya, Gang Merdeka XVII Pagesangan Mataram. Pada proses pelatihan yang diberikan menunjukkan adanya tanggapan positif dari peserta kegiatan. Hal ini teramati dari kesungguhan dan keingintahuan lebih lanjut para peserta tentang obat tradisional untuk typhus dan adanya pertanyaan-pertanyaan yang diajukan selama proses pelatihan. Selain itu juga para peserta memiliki keinginan untuk mengimplementasikan pengetahuan yang diperoleh untuk meningkatkan kesehatan keluarga dan masayarakat. Evaluasi random dalam bentuk pertanyaan singkat dan wawancara menunjukkan para peserta dapat menjawab dengan baik dan memberikan contoh-contoh obat tradisional di lingkungannya yang dapat dimanfaatkan untuk mencegah penyakit typhus selain yang disampaikan oleh narasumber. Berdasarkan data yang diperoleh dapat disimpulkan bahwa proses peningkatan pemahaman masyarakat Pagesangan Mataram telah berhasil dilaksanakan. Kegiatan ini diharapkan dapat dijadikan sebagai langkah awal untuk peningkatan peran masyarakat dalam menjaga kesehatan dan lingkungannya serta perlu ditindaklanjuti secara kontinyu sehingga masyarakat lebih merasa berkontribusi dan dibutuhkan.

Kata Kunci: Penyakit typhus, Obat Tradisional, SDIT Anak Sholeh, Pagesangan Mataram 


\section{PENDAHULUAN}

\section{A. Analisis Situasi}

Penyakit typhus merupakan penyakit infeksi usus halus yang disebabkan oleh bakteri Salmonella typhi. Bakteri Salmonella typhi dapat masuk ke dalam tubuh manusia melalui makanan dan minuman yang tercemar bakteri tersebut. Penyakit typhus masih merupakan penyakit endemi terutama di Indonesia dan Negara-negara berkembang lainnya. Sebanyak 358-810 orang/100.000 penduduk Indonesia pada tahun 2007 menderita tipus [Hatta dan Smits, 2007]. Penyakit typhus diketahui juga menyerang semua usia mulai anak-anak sampai orang dewasa. Oleh karena itu diperlukan suatu cara untuk memberikan pemahaman, pencegahan dan penatalaksanaan pasien demam tipus pada masayarakat.

Penyakit typhus tergolong penyakit dalam kadar ringan. Tetapi, proses pemulihan untuk penyakit tipus membutuhkan waktu cukup lama. Berdasarkan hal tersebut maka informasi tentang asupan gizi, perawatan yang tepat, pemanfaatan obat tradisional, juga merupakan informasi sangat penting untuk diketahui oleh masyarakat, baik masyarakat perkotaan maupun pedesaan.

Proses penyampaian informasi dan sosialisasi hasil penelitian tentang penyakit typhus dari perguruan tinggi kepada masyarakat dapat dilakukan dengan berbagai cara. Salah satu caranya adalah melalui program pengabdian pada masyarakat yang dilakukan oleh akademisi sebagai pelaksanaan tri dharma perguruan tinggi.

Wilayah yang akan dijadikan tempat pengabdian masyarakat adalah Desa Pagesangan Barat Kecamatan Mataram Kotamadya Mataram Provinsi Nusatenggara Barat yang berada di Pulau Lombok. Provinsi Nusa Tenggara Barat terdiri dari dua pulau besar yaitu Pulau Lombok dan Pulau Sumbawa. Kota Mataram sebagai ibukota Provinsi Nusa Tenggara Barat terletak di Pulau Lombok. Gambar pulau Lombok dan Kotamadya Mataram beserta kecamatan di wilayah Mataram disajikan pada gambar 1 .

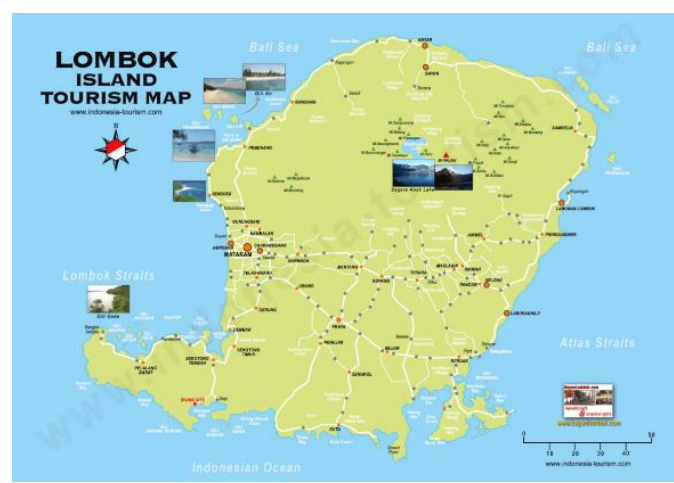

Gambar 1. Peta Provinsi Nusa tenggara Barat. Pulau Lombok adalah bagian dari Provinsi Nusa Tenggara Barat (NTB) yang terbagi ke dalam 4

Kabupaten dan 1 Kotamadya, yakni Kotamadya Mataram, Kabupaten Lombok Barat, Lombok Tengah, Lombok Timur, dan lombok Utara. [sumber: wisatalombokaja.blogspot.co.id].

Luas wilayah Kota Mataram adalah 61.30 $\mathrm{km}^{2}$ (6.130 Ha). Pada 2007 Kota Mataram mengalami pemekaran wilayah dari tiga kecamatan dan 23 kelurahan menjadi enam kecamatan dan 50 kelurahan. Secara geografis Kota Mataram terletak pada posisi 116o04' 116 o 10' Bujur Timur, dan 08 o 33'- 08 o 38' Lintang Selatan dengan batas batas wilayah: Sebelah Utara: Kecamatan Gunungsari, Kecamatan Batulayar dan Kecamatan Lingsar Kabupaten Lombok Barat. Sebelah Timur: Kecamatan Narmada dan Kecamatan Lingsar Kabupaten Lombok Barat. Bagian Selatan: Kecamatan Labuapi Kabupaten Lombok; Bagian Barat : Selat Lombok.

Wilayah Kota Mataram merupakan dataran rendah dan sedang, dan sebagian lain berada pada ketinggian 50 meter di atas permukaan laut (mdpl). Kondisi tersebut menunjukkan bahwa sebagian besar wilayah Kota Mataram adalah hamparan datar (75.9\%). Daerah datar-landai berada di bagian barat serta agak tinggi-bergelombang di bagian timur. Kota Mataram memiliki topografi wilayah berada pada ketinggian kurang dari 50 meter di atas permukaan laut (dpl) dengan rentang ketinggian sejauh $9 \mathrm{~km}$, terletak pada $08^{\circ} 33^{\prime}$ - $08^{\circ} 38^{\prime}$ Lintang Selatan dan $116^{\circ} 04^{\prime}-116^{\circ} 10^{\prime}$ Bujur Timur. Struktur geologi Kota Mataram sebagian besar adalah jenis tanah liat dan tanah endapan tuff yang 
E-ISSN: 2597-8926

merupakan endapan alluvial yang berasal dari kegiatan Gunung Rinjani, secara visual terlihat seperti lempengan batu pecah, sedangkan di bawahnya terdapat lapisan pasir. Diketahui pula bahwa pendudukan kota mataram dan di sekitar pulau Lombok masyarakat masih memelihara dengan baik budaya tradisional yang dimiliki, dan masih diimplementasikan dalam kehiduapn sehariseharinya.

Secara administratif Kotamadya Mataram memiliki luas daratan $61,30 \mathrm{~km}$ dan $56,80 \mathrm{~km}$ perairan laut, terbagi atas 6 kecamatan, yaitu Kecamatan Ampenan, Cakranegara, Mataram, Sandubaya, Selaparang dan Sekarbela dengan 50 kelurahan dan 297 lingkungan. Pada tabel 1 disajikan nama kecamatan yang ada di Kota Mataram.

Suhu udara di Kota Mataram berkisar antara $20.4{ }^{\circ} \mathrm{C}$ sampai dengan $32.10{ }^{\circ} \mathrm{C}$. Kelembaban maksimum $92 \%$ terjadi pada bulan Januari, April, Oktober dan November, sedangkan kelembaban minimum $67 \%$ terjadi pada bulan Oktober. Rata-rata penyinaran matahari maksimum pada bulan Februari. Sementara jumlah hari hujan tertinggi terjadi pada bulan November sebanyak 27 hari, dengan curah hujan rata-rata mencapai $1.256,66 \mathrm{~mm}$ per tahun, dan jumlah hari relatif 110 hari per tahun. Tingginya curah hujan dan kelembaban yang tinggi, hal ini memungkinkan berkembang biaknya penyakit-penyakit tropis seperti penyakit typhus

Berdasarkan demografi wilayah Kota Mataram memiliki luas wilayah terkecil di Provinsi Nusa Tenggara Barat, tetapi dihuni oleh jumlah penduduk yang besar. Jumlah penduduk tersebut dapat menjadi potensi tenaga kerja sebagai modal pembangunan di segala bidang. Jumlah penduduk Kota Mataram sesuai data BPS Kota Mataram, 2009 sebanyak 375.506 jiwa dengan perbandingan jumlah penduduk laki-laki terhadap penduduk perempuan (rasio jenis kelamin) sebesar 0.97, sedangkan tingkat kepadatan penduduknya mencapai 6.126 jiwa per kilometer persegi dengan laju pertumbuhan sebesar 3,66 persen. [Profilkota-mataram-nusatenggara-barat, 2016].

Tabel 1. Nama Kecamatan/Kelurahan di Kota Mataram

[Bappeda Kota Mataram, 2011]

\begin{tabular}{|c|c|c|c|c|c|}
\hline \multirow{2}{*}{1} & \multirow{2}{*}{$\begin{array}{c}\text { KECAMAT } \\
\text { AN } \\
\text { Ampenan }\end{array}$} & \multicolumn{4}{|c|}{ KELURAHAN } \\
\hline & & 1 & Bintaro & 6 & $\begin{array}{l}\text { Ampenan } \\
\text { Utara }\end{array}$ \\
\hline & & 2 & $\begin{array}{l}\text { Ampenan } \\
\text { Utara }\end{array}$ & 7 & $\begin{array}{l}\text { Taman } \\
\text { Sari }\end{array}$ \\
\hline & & 3 & $\begin{array}{l}\text { Dayan } \\
\text { Peken }\end{array}$ & 8 & Perejuk \\
\hline & & 4 & $\begin{array}{l}\text { Amp. } \\
\text { Tengah }\end{array}$ & 9 & $\begin{array}{l}\text { Kebun } \\
\text { Sari }\end{array}$ \\
\hline & & 5 & Banjar & 10 & $\begin{array}{l}\text { Pejarakan } \\
\text { Karya }\end{array}$ \\
\hline \multirow[t]{3}{*}{2} & Sekarbela & 1 & $\begin{array}{l}\text { Kekalik } \\
\text { Jaya }\end{array}$ & 4 & $\begin{array}{l}\text { Karang } \\
\text { Pule }\end{array}$ \\
\hline & & 2 & $\begin{array}{l}\text { Tj. Kr. } \\
\text { Permai }\end{array}$ & 5 & $\begin{array}{l}\text { Jempong } \\
\text { Baru }\end{array}$ \\
\hline & & 3 & $\begin{array}{l}\text { Tanjung } \\
\text { Karang }\end{array}$ & & \\
\hline \multirow[t]{4}{*}{3} & Mataram & 1 & Pejanggik & 6 & $\begin{array}{l}\text { Pagesang } \\
\text { an Timur }\end{array}$ \\
\hline & & 2 & Punia & 7 & Pagutan \\
\hline & & 3 & $\begin{array}{l}\text { Pagesang } \\
\text { an Barat }\end{array}$ & 8 & $\begin{array}{l}\text { Pagutan } \\
\text { Timur }\end{array}$ \\
\hline & & 4 & $\begin{array}{l}\text { Pagesang } \\
\text { an }\end{array}$ & & \\
\hline \multirow[t]{5}{*}{4} & Selaparang & 1 & Rembiga & 6 & $\begin{array}{l}\text { Mataram } \\
\text { Barat }\end{array}$ \\
\hline & & 2 & $\begin{array}{l}\text { Karang } \\
\text { Baru }\end{array}$ & 7 & Gomong \\
\hline & & 3 & $\begin{array}{l}\text { Monjok } \\
\text { Timur }\end{array}$ & 8 & $\begin{array}{l}\text { Dasan } \\
\text { Agung }\end{array}$ \\
\hline & & 4 & Monjok & 9 & $\begin{array}{l}\text { Dasan } \\
\text { Agung } \\
\text { Baru }\end{array}$ \\
\hline & & 5 & $\begin{array}{l}\text { Monjok } \\
\text { Barat }\end{array}$ & & \\
\hline \multirow[t]{5}{*}{5} & Cakranegara & 1 & $\begin{array}{l}\text { Cakraneg } \\
\text { ara Barat }\end{array}$ & 6 & $\begin{array}{l}\text { Cakraneg } \\
\text { ara } \\
\text { Selatan }\end{array}$ \\
\hline & & 2 & Cilinaya & 7 & $\begin{array}{l}\text { Cakraneg } \\
\text { ara } \\
\text { Selatan } \\
\text { Baru }\end{array}$ \\
\hline & & 3 & $\begin{array}{l}\text { Sapta } \\
\text { Marga }\end{array}$ & 8 & $\begin{array}{l}\text { Cakraneg } \\
\text { ara Utara }\end{array}$ \\
\hline & & 4 & Mayura & 9 & $\begin{array}{l}\text { Karang } \\
\text { Taliwang }\end{array}$ \\
\hline & & 5 & $\begin{array}{l}\text { Cakraneg } \\
\text { ara Timur }\end{array}$ & 10 & $\begin{array}{l}\text { Sayang } \\
\text { Sayang }\end{array}$ \\
\hline \multirow[t]{4}{*}{6} & Sandubaya & 1 & Selagalas & 5 & Turida \\
\hline & & 2 & Bertais & 6 & $\begin{array}{l}\text { Abian } \\
\text { Tubuh } \\
\text { Baru }\end{array}$ \\
\hline & & 3 & $\begin{array}{l}\text { Mandalik } \\
\text { a }\end{array}$ & 7 & $\begin{array}{l}\text { Dasan } \\
\text { Cermen }\end{array}$ \\
\hline & & 4 & Babakan & & \\
\hline
\end{tabular}

Berdasarkan data sementara yang ada di BPS tahun 2012, jumlah penduduk kota Mataram tercatat 406,910, terdiri dari Kecamatan Ampenan dengan jumlah Jurnal Sarwahita Vol. 14 No. 02 Tahun 2017 | 116 
E-ISSN: 2597-8926

penduduk sebesar 79.367 jiwa, Kecamatan Sekarbela sebesar 53.946 jiwa, Kecamatan Selaparang sebesar 73,222 jiwa, Kecamatam Mataram sebesar 73.921 jiwa, Kecamatan Sandubaya sebesar 61,683 jiwa dan Kecamatan Cakranegara sebesar 64,771 jiwa. Rata-rata orang per KK untuk masing-masing kecamatan adalah $4-5$ orang per KK.

Profil kesehatan kota Mataram yang dilapor pada tahun 2005-2009 menunjukkan bahwa dalam lima tahun terakhir derajat kesehatan masyarakat Kota Mataram mengalami peningkatan yang cukup tinggi, indikatornya adalah penurunan angka kematian bayi, umur harapan hidup serta prevalensi gizi buruk. Salah satu usaha yang dilakukan pemerintah untuk meningkatkan derajat kesehatan adalah dengan penyediaan fasilitas kesehatan yang lebih baik dari tahun ke tahunnya. Namun bila bila dilihat cakupan layanan kesehatan rujukan untuk masyarakat miskin masih memiliki angka yang rendah yaitu $0.23-3.22 \%$. Ada beberapa hal yang mungkin menjadi penyebab, di antaranya adalah: 1) masih kurangnya fasilitas, 2) masih digunakannya pola pengobatan tradisional yang ada di masayarakat, Berdasarkan hal tersebut maka pengenalan dan cara pengolahan obat tradisional yang baik perlu disosialisasi di masyarakat sehingga penggunaannya menjadi terstandar yang memberikan manfaat yang lebih optimal.

Melihat pada kondisi alam dan situasi masyarakat kota Mataram maka sangat penting dilakukan sosialisasi tentang Pemanfaatan Obat-Obat Tradisional Dalam Mencegah Dan Mengobati Penyakit Typhus

Sebagai Upaya Peningkatan Hidup

Sehat Pada Masyarakat Pagesangan Barat Mataram. Sehingga diharapkan kegiatan pengabdian kepada masyarakat yang dilakukan oleh dosen dari Universitas Negeri Jakarta, dapat berperan aktif dalam menyebarluaskan IPTEKS sebagai produk yang telah diketahui dan dimanfaatkan untuk meningkatkan kualitas hidup masyarakat pulau Lombok khususnya masyarakat desa Pagesangan Barat Mataram.

\section{B. Perumusan Masalah}

Berdasarkan analisis situasi yang telah diuraikan, maka perumusan masalah yang diajukan pada program pengabdian pada masyarakat ini adalah : "Bagaimana upaya konkrit untuk melakukan Pemanfaatan ObatObat Tradisional Dalam Mencegah Dan Mengobati Penyakit Typhus Sebagai Upaya Peningkatan Hidup Sehat Pada Masyarakat Pagesangan Barat Mataram melalui kegiatan pengabdian masyarakat yang dilakukan oleh tim dari FMIPA UNJ?"

\section{Tujuan Kegiatan}

Tujuan PkM ini adalah:

Meningkatkan pengetahuan tentang Pemanfaatan Obat-Obat Tradisional Dalam Mencegah Dan Mengobati Penyakit Typhus Sebagai Upaya Peningkatan Hidup Sehat Pada Masyarakat Pagesangan Barat Mataram. (2) Melakukan sosialisasi dan pelatihan tentang tentang Pemanfaatan Obat-Obat Tradisional Dalam Mencegah Dan Mengobati Penyakit Typhus secara interaktif dan komunikatif sehingga diharapkan masyarakat dapat lebih memahami dan mengimplementasikan pengetahuannya dalam peningkatan kualitas hidup khususnya di Desa Pagesangan Barat Mataram.

\section{Manfaat Kegiatan}

Program pengabdian kepada masyarakat ini diharapkan dapat memberikan manfaat sebagai berikut: (1) Masyarakat Desa Pagesangan Barat Mataram memiliki pengetahuan tentang pemanfaatan obat-obat tradisional dalam mencegah dan mengobati penyakit typhus. (2) Pengetahuan yang diperoleh setelah mengikuti program ini diharapkan dapat dimanfaatkan masyarakat untuk meningkatkan kualitas hidup dan pembiasaan hidup sehat di Desa Pagesangan Barat Mataram. (3) Pengetahuan yang diperoleh setelah mengikuti program ini diharapkan dapat dimanfaatkan masyarakat untuk meningkatkan kualitas hidup dan pembiasaan hidup sehat di Desa Pagesangan Barat kecamatan Mataram. 


\section{METODE PELAKSANAAN PENGABDIAN MASYARAKAT}

\section{A. Kerangka Pemecahan Masalah}

Salah satu upaya penyebarluasan teknologi pencegahan penyakit typhus dapat berhasil adalah dengan cara memberikan penyuluhan dan pelatihan kepada masyarakat yang berpotensi. Melalui penyuluhan ini, diharapkan informasi penting yang berkaitan tentang kajian teoritis dan berbagai informasi seputar penyakit typhus, gejala, pencegahan dan penatalaksanaan pasien typhus, obat-obat tradisional yang dapat digunakan sebagai pensegah penyakit typhus sampai kepada peserta dengan efektif, baik melalui metode ceramah, diskusi, tanya jawab atau kombinasi antara metode tersebut. Melalui kombinasi metode yang digunakan ini, diharapkan semua informasi dapat sampai dengan efektif dan dapat meningkatkan pengetahuan dan wawasan para peserta kegiatan pelatihan ini, sehingga pada akhirnya dapat dimanfaatkan dalam meningkatkan kualitas hidup keluarga pada khususnya dan masyarakat desa Desa Pagesangan Barat kecamatan Mataram pada umumnya.

\section{B. Realisasi Pemecahan Masalah}

Metode yang digunakan dalam menjalankan program pengabdian masyarakat ini adalah: Diskusi informasi, dan tanya jawab. Metode tersebut dilakukan melalui tahap-tahap:

1. Pendahuluan. Pada tahap ini dilakukan pengumpulan data mengenai kebiasaan hidup diwilayah setempat dan keadaan alam Desa Pagesangan Barat kecamatan Mataram melalui kegiatan survey lokasi atau diskusi informasi.

2. Pelaksanaan. Penyuluhan kepada ibu-ibu rumah tangga, remaja, dan pendidik dengan haparan, informasi penting yang berkaitan tentang pengenalan gejala, pencegahan, penatalaksanaan dan obatobat tradisional yang berada dilingkungannya dan dapat digunakan untuk mencegah penyakit typhus sampai kepada peserta dengan efektif, baik melalui metode ceramah, diskusi, tanya jawab atau kombinasi antara metode tersebut.

3. Evaluasi. Pada tahap ini dilakukan evaluasi hasil dari kegiatan berupa analisa proses dan hasil yang diperoleh.

\section{Khalayak Sasaran}

Khalayak sasaran yang strategis dalam program pengabdian kepada masyarakat yang diselenggarakan ini adalah ibu-ibu rumah tangga, para remaja, dan pendidik yang merupakan tenaga potensial yang memiliki kemauan dan kemampuan untuk terlibat dan berpartisipasi aktif dalam program yang diselenggarakan.

\section{Keterkaitan}

Keterkaitan FMIPA, Universitas Negeri Jakarta dengan program ini adalah: (1) Fakultas Matematika dan Ilmu Pengetahuan Alam sebagai Lembaga yang bertanggung jawab dalam pengembangan pelaksanaan Tri Dharma Perguruan Tinggi di lingkunagn FMIPA. (2) Lembaga Penelitian dan Pengabdian Kepada Masyarakat (LPPM) Universitas Negeri Jakarta yang bertugas untuk mengembangkan program kerjasama dalam pembinaan masyarakat. (3) Prodi Pendidikan Kimia dan Kimia FMIPA, Universitas Negeri Jakarta sebagai unit yang memiliki dosen dilingkungan FMIPA. (4) Kepala Desa dan Kepala Sekolah di lingkungan Desa Pagesangan Barat kecamatan Mataram sebagai Pimpinan dan pengambil kebijakan dalam peningkatan kualitas pendidikan dan sekolah. (5) Para remaja, ibu-ibu rumah tangga, dan pendidik yang merupakan tenaga potensial dan memiliki kemauan dan kemampuan untuk terlibat dan berpartisipasi aktif dalam program yang diselenggarakan.

\section{E. Metode Kegiatan}

Metode yang digunakan dalam menjalankan program pengabdian masyarakat ini adalah: Pelatihan dengan ceramah, diskusi informasi dan tanya jawab.

\section{F. Materi Kegiatan}

Materi yang disampaikan pada saat pelaksanaan kegiatan adalah sebagai berikut. (1) Apa itu Penyakit typhus? (2) Bakteri Jurnal Sarwahita Vol. 14 No. 02 Tahun 2017 | 118 
DOI: https://doi.org/10.21009/sarwahita.142.05

P-ISSN: 0216-7484

E-ISSN: 2597-8926

Penyebab Penyakit typhus; (3) Bagaimana Bakteri Penyebab Penyakit typhus masuk dalam tubuh; (4)Bagaimana Gejala Penyakit typhus; (5) Apa akibatnya dan Bagaimana mencegahnya?; (6) Makanan Apa yang boleh dikonsumsi oleh pasien penyakit typhus?

(7) Bagaimana merawat pasien penyakit typhus dan pengobatannya? (8) Lima hal penting yang harus diketajui terkait penyakit typhus; (9) Obat-obat tradisional yang dapat digunakan untuk mencegah penyakit typhus; (10) Apa yang sedang dilakukan di UNJ terkait dengan obat dan metode deteksi untuk penyakit typhus.

\section{G. Evaluasi}

Keberhasilan program pengabdian kepada masyarakat dievaluasi dengan indikator sebagai berikut: (1) Jumlah peserta yang terlibat dalam program. (2) Peserta antusias mengikuti kegiatan dengan banyak mengajukan pertanyaan tentang materi dan implementasinya. (3) Peserta dapat memperoleh materi pelatihan dengan optimal.

(4) Peserta mampu mengimplementasikan pengetahuan yang diterimanya.

\section{HASIL DAN PEMAHASAN}

Pelaksanaan program pengabdian kepada masyarakat tahun 2017 dilakukan di SDIT Anak Sholeh Mataram, Jl. Merdeka Raya, Gang Merdeka XVII Pagesangan Mataram telah dilaksanakan pada hari Jumat, 7 September 2017. Program Pengabdian Masyarakat (P2M) dilakukan secara bersamasama dengan dosen Prodi Kimia dan Pendidikan Kimia FMIPA UNJ. Salah satu dokumentasi pelaksanaan pelatihan disajikan pada gambar 2 .

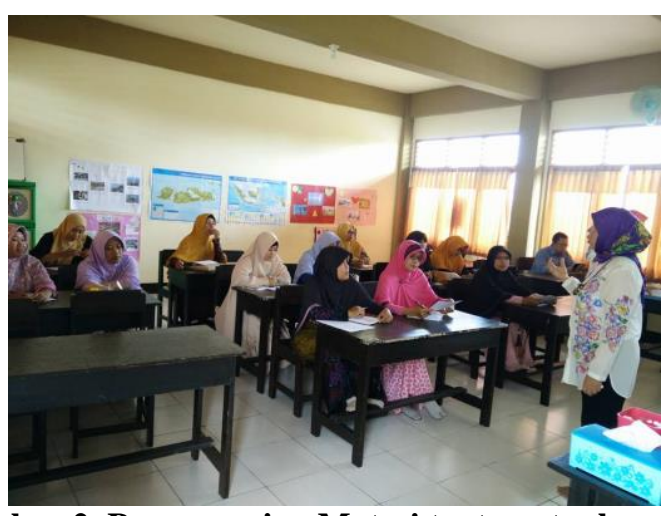

Gambar 2. Penyampaian Materi tentang typhus. Ketua tim pelaksnaan pengabdian masyarakat sedang menyajikan materi tentang "Pemanfaatan Obat-obat Tradisional dalam Mencegah dan mengobati Penyakit Typhus Sebagai Upaya Peningkatan Kualitas hidup Masyarakat Pagesangan Barat Mataram“.” di SDIT Anak Sholeh Mataram.

Acara pelatihan tentang penyakit Typhus masuk dalam kelompok bidang kesehatan dan reproduksi. Pelaksanaan pelatihan bidang kesehatan dipandu oleh tim dosen secara bergantian sesuai dengan materi akan disampaikan, dan setiap dosen diberi kesempatan untuk menjadi pemateri dan sebagai moderator. Sehingga peserta pelatihan dapat dipandu dalam melaksankan diskusi dan tanya jawab dan suasana menjadi lebih akrab.

Tanggapan Peserta terhadap pelaksanaan pelatihan sangat positif. Hal ini teramati dari kesungguhan dan keingintahuan lebih lanjut para peserta dalam mengikuti pelatihan dan adanya pertanyaan-pertanyaan yang diajukan selama proses pelatihan diantaranya meliputi : (1) Penyebab bakteri typhus dan perbedaannya dengan para-typhus; (2) Apakah kalau disebut gejala typhus itu juga sakit typhus; (3) Perbedaan ciri-ciri bila terkena penyakit typhus pada anak-anak dan dewasa; (4) Penatalaksanaan pasien penyakit typhus pada anak-anak dan bayi; (5) Makanan-makanan yang dapat dikonsumsi oleh pasien yang terkena penyakit typhus; (6) Apakah penyakit typhus dapat menyerang kembali, bagaimana sebaiknya bila terkena penyakit typhus yang ke dua kalinya; (7) Apakah penyakit typhus dapat komplikasi dengan penyakit-penyakit lainnya, bagaimana mengatasi hal tersebut (8) Kapan obat-obat tradisional dapat dikonsumsi agar efektif; (9) 
Bagaimana cara penyediaan obat-obat tradisioanl sebagai obat typhus;

Apakah cacing tanah dapat dijadikan obat typhus; (11) Jenis Cacing tanah apa yang dapat dijadikan obat typhus.

Berdasarkan analisis pertanyaanpertanyaan yang diajukan oleh para peserta pelatihan, maka dapat disimpulkan bahwa peserta dapat dengan baik menyerap informasi yang disampaikan oleh tim pengabdian masyarakat. Selain itu pertanyaan yang lebih mendalam juga menunjukkan bahwa peserta sangat antusias dalam memahami materi tentang typhus.

Setelah penyampaian materi dan tanya jawab, tim pelaksana pengabdian juga melakukan wawancara secara random pada beberapa peserta pelatihan pada saat istirahat dan makan siang bersama. Berdasarkan hasil wawancara dengan peserta pelatihan, program pelatihan ini dianggap sangat bermanfaat karena: (1) Menambah dan memperluas wawasan pengetahuan para peserta tentang Pengenalan Gejala, Pencegahan, dan Penatalaksanaan Penyakit Typhus; (2) Peningkatan wawasan tentang pemanfatan daun, buah dan sumber daya alam di sekitarnya yang dapat dijadikan sebagai obat penyakit typhus; (3) Penyakit typhus sering ditemukan di Desa Pagesangan Barat Mataram, dan banyak pula keluarga yang pernah terjangkit penyakit typhus sehingga pengetahuan tentang materi yang disajikan dianggap sangat bermanfaat; (3) Para peserta berkeinginan lebih lanjut menjaga sanitasi lingkungan dan pemanfaatan obat tradisional yang ada di daerahnya untuk mencegah penyakit typhus; (4) Pengetahuan yang diperoleh setelah mengikuti pelatihan ini dapat diterapkan dan dimanfaatkan langsung setelah mengikuti kegiatan untuk menciptakan hidup bersih dan meningkatkan kualitas hidup baik di rumah maupun di lingkungan desa Pagesangan Barat; (5) Para peserta pelatihan ingin mencoba berbagai abot tradisional yang didiskusikan sebagai pencegah penyakit typhus.
Keberhasilan pelaksanaan kegiatan pengabdian kepada masyarakat di desa Pagesangan Barat ini tidak terlepas dari:

1. Adanya kesungguhan peserta dalam mengikuti kegiatan yang diselenggarakan dari awal sampai akhir;

2. Aktifnya para peserta untuk menanyakan tentang materi yang tidak dimengerti selama tim menyampaikan materi, diskusi, dan tanya jawab yang dilakukan;

3. Keinginan peserta untuk mengimplementasikan pengetahuan yang diperoleh untuk meningkatkan kesehatan keluarga dan masayarakat;

4. Dukungan dari pejabat setempat dan Kepala Sekolah SDIT Anak Sholeh yang memberikan kemudahan dalam perizinan, himbauan pada masyarakat dan penyebaran undangan untuk mengikuti kegiatan pengabdian masyarakat yang dilaksanakan;

5. Terpenuhinya semua indicator keberhasilan yang ditetapkan pada evaluasi yang dilaksanakan yaitu meliputi jumlah peserta, aktivitas peserta, pemahaman peserta, serta keinginan peserta dalam mengimplementasikan pengetahuan yang diperolehnya.

\section{PENUTUP}

Kesimpulan dari pelaksanaan pelatihan pada program pengabdian masyarakat di SDIT Anak Sholeh Desa Pagesangan Barat Mataram adalah: (1) Kegiatan pengabdian kepada masyarakat dengan judul "Pemanfaatan Obat-Obat Tradisional Dalam Mencegah Dan Mengobati Penyakit Typhus Sebagai Upaya Peningkatan Hidup Sehat Pada Masyarakat Pagesangan Barat Mataram." telah berhasil dilakukan, dan dapat dijadikan alternative dalam pengembangan program pelatihan peningkatan pengetahuan masyarakat tentang peningkatan kualitas hidup dan pembiasaan hidup sehat baik di rumah maupun dilingkungan masyarakatnya. (2) Sosialisasi cara hidup sehat dan pemanfaatan obat-obat tradisional yang ada dilingkungan sekitar juga bisa diterapkan pada siswa sekolah dasar sebagai pengetahuan awal 
dalam peningkatan kualitas hidup sehat dan pencegahan penyakit typhus.

\section{DAFTAR PUSTAKA}

Cleary TG. Salmonella. Dalam : Behrman RE, Kliegman RM, Jenson HB, Eds. Nelson Textbook of Pediatrics, edisi 16. Philadelphia : WB Saunders, 2000:842-

Data Statistik dari Badan Pusat Statistik. Pengangguran Terbuka Menurut Pendidikan Tertinggi yang Ditamatkan. http://www.bps.go.id/ tab_sub/excel.php?id_subyek=06\%20 \&notab=4. (Akses pada 4 April 2016). Diagnosis of typhoid fever. Dalam : Background document : The diagnosis, treatment and prevention of typhoid fever. World Health Organization, 2003;7-18.

Fraser A, Goldberg E, Acosta CJ, Paul M, Leibovici L (2007). Fraser, Abigail, ed. "Vaccines for preventing typhoid fever". Cochrane Database Syst Rev (3):CD001261.doi:10.1002/14651858 .CD001261.pub2. PMID 17636661.

Hatta M, Goris MG. Simple dipstick assay for the detection of Salmonella typhispecific IgM antibodies and the evolution of the immune response in patients with typhoid fever. Am J Trop Med Hyg 2002;66(4):416-21.

Giannella RA (1996). "Salmonella". Baron's Medical Microbiology (Baron S et al, eds.) (4th ed. ed.). Univ of Texas Medical Branch. ISBN 0-9631172-11.

Hoffman SL. Typhoid Fever. Dalam : Strickland GT, Ed. Hunter's Textbook of Pediatrics, edisi 7. Philadelphia : WB Saunders, 1991:344-58.

http://www.pustakasekolah.com/penyakittyphus-dan-pengobatannya.html. Diakses pada tanggal 10 April 2016. http:// profil-kota-mataram-nusatenggarabarat.html). Diakses pada tanggal 10 Maret 2017. http://kotamataram.silh.menlh.go.id/jumlahpenduduk-di-kota-mataram/ diakses pada tanggal 10 Maret 2017.

(http://dedaunan.com/berbagai-pilihan-obatsakit-tipes-dari-bahan-alami/2) diakses pada tanggal 10 Maret 2017.

Kalra SP, Naithani N, Mehta SR, Swamy AJ. Current trends in the management of typhoid fever. MJAFI 2003;59:130-5.

Lim PL, Tam FCH, Cheong YM, Jegathesan M. One-step 2-minute test to detect typhoid-specific antibodies based on particle separation in tubes. J Clin Microbiol 1998;36(8):2271-8.

Massi MN, Shirakawa T, Gotoh A, Bishnu A, Hatta M, Kawabata M. Rapid diagnosis of typhoid fever by PCR assay using one pair of primers from flagellin gene of Salmonella typhi. J Infect Chemother 2003;9(3):233-7

Muktiningsih Nurjayadi, Fera Kurniadewi, Fernita Puspitasari., 2013. Pengembangan Potensi Molekul Bioaktif Fim-C Salmonella typhi Sebagai Kandidat Vaksin Rekombinan Dalam Mencegah Penyakit Typhus Pada Manusia. Laporan Akhir Penelitian Strategis Nasional. Direktorat Penelitian dan Pengabdian Kepada Masyarakat Direktorat Jenderal Pendidikan Tinggi Kementerian Pendidikan dan Kebudayaan sesuai dengan surat perjanjian pelaksanaan penugasan penelitian strategis nasional NO: 123/SP2H/PL/DIT.LITABMAS/V/20 13, TANGGAL 13 MEI 2013

Muktiningsih Nurjayadi, Fera Kurniadewi, Irma Ratna Kartika, Suhartono, Restu Nidia Sandra, Fitri Wulandari, Taufan Ardianto, Dalia Sukmawati, Wibowo Mangunwardoyo. 2015. Fimbrial-C S.typhi Primer As Clinical Detection of Typhoid Disease by PCR Methods. Proceding International Symposium on Current Progress in Mathematics and Science. UI Depok. 3-4 November 2015. 
DOI: https://doi.org/10.21009/sarwahita.142.05

P-ISSN: 0216-7484

E-ISSN: 2597-8926

Muktiningish Nurjayadi, Listya ayu Saraswati,Irma Ratna Kartika, 2016. Pengenalan gejala, Pencegahan, dan Penatalaksnaan Penyakittyphus sebagai Upaya Peningkatan Kualitas hidup Sehat Masyarakat Tanjung Pandan Belitung. Laporan P2M Dana BLU FMIPA UNJ.

Parry CM. Typhoid fever. N Engl J Med 2002;347(22):1770-82.

Pang T. Typhoid Fever : A Continuing Problem. Dalam : Pang T, Koh CL, Puthucheary SD, Eds. Typhoid Fever : Strategies for the 90's. Singapore : World Scientific, 1992:1-2.

Pang T. Molecular biology as a diagnostic tool in Salmonellosis. Dalam : Sarasombath S, Senawong S, Eds. Second Asia-Pacific symposium on typhoid fever and other Salmonellosis. Thailand : SEAMEO Regional Tropical Medicine and Public Health Network, 1995:213-6.

Pedoman Kegiatan Penelitian dan Pengabdian Pada Masyarakat Edisi X. Kemenristekdikti. 2016

Purwaningsih S, Handojo I, Prihatini, Probohoesodo Y. Diagnostic value of dot-enzyme-immunoassay test to detect outer membrane protein antigen in sera of patients with typhoid fever. Southeast Asian J Trop Med Public Health 2001;32(3):507-12.

Tumbelaka AR, Retnosari S. Imunodiagnosis Demam Tifoid. Dalam : Kumpulan Naskah Pendidikan Kedokteran Berkelanjutan Ilmu Kesehatan Anak XLIV. Jakarta : BP FKUI, 2001:65-73.

World Economic Forum. The Indonesia Competitiveness Report 2011: Sustaining the Growth Momentum. http://www3.weforum.org/docs/

WEF_GlobalCompetitivenessReport 2014-15. pdf. Di Akses 4 April 2016. Pukul 07:03 WIB.

www.klinikanakonline.com diakses pada tanggal 10 April 2016 